\title{
Student Union Election Discourse in Nigeria:
} The Stylo-pragmatics

\author{
${ }^{* 1}$ Acheoah, John Emike, PhD, ${ }^{2}$ Olaleye, Joel Iyiola, ${ }^{3}$ Hamzah Abdulraheem, PhD \\ ${ }^{1}$ Department of European Languages, Faculty of Arts, Management and Social Sciences \\ Federal University, Birnin-kebbi, Nigeria \\ ${ }^{2}$ Department of English, Waziri Umaru Federal Polytechnic, Birnin Kebbi, Kebbi State, Nigeria \\ ${ }^{3}$ College of the Humanities, Department of Languages, Al-Hikmah University, Ilorin, Nigeria \\ actualemike@gmail.com
}

Received Date: July 07, 2017

Accepted Date: July 13, 2017

Published Date: July 24, 2017

Abstract: Candidates (students) aspiring for posts in Nigerian tertiary institutions usually engage in pre-election discourses (election campaigns) to convince prospective voters that they have clear, comprehensive manifestoes to actualize if voted into power as Student Union President, Treasurer, Public Relations Officer (PRO), and other positions of authority in their respective campuses. The campaigns take a more organized, elaborate and persuasive dimension on the day popularly known as "Manifesto Night". This study investigates the pragmatic and stylistic features of Student Union Election discourses in Nigerian tertiary institutions, using a university as a case study. Only five micro-structures are selected from a campaign speech (macro-structure) of an aspirant who is popularly known as Plato. Hinging on Bach and Harnish's Speech Act Theory and Lawal's Communicative Model Theory, this study finds out that Student Union Election discourse in Nigerian tertiary institutions is characterized by a wide range of pragmatic and stylistic strategies which essentially make it persuasively potent. These strategies include: good introduction, allusion, elaboration, skilful selection of speech acts, use of people-inclusive personal pronouns, reliance on figurative language, reminiscences, repetitions, direct call to action and blunt attack on status-quo.

Keywords: Student Union campaigns, Nigerian universities, stylistics, pragmatics, speech act theory, Communicative Model Theory

\section{INTRODUCTION}

This study is a linguistic analysis of language use in an election campaign discourse. The speaker is aspiring to become the next President of the Student Union Government of the University where he studies Political Science. We analyze selected corpora from the entire speech he delivers to the student population at the Manifesto Night. Since the study is interested in the persuasive use of language in election campaign discourses in Nigerian tertiary institutions, it is essentially a research in stylistics, pragmatics and related disciplines. This understanding directs the literature review, analysis and discussion sections of the study.

\section{Textual Analysis, Pragmatics and Stylistics}

It is interesting that insights from pragmatics and stylistics are crucial in the investigation of language use across genres. The application of pragmatic and stylistic theories to textual analysis indicates a clear-cut departure from how texts were analysed when modern linguistics evolved. At the inception of modern linguistics, the practice was for analysts to confine the analysis of a text to the domain of sentence which was, then, regarded as the largest unit with an inherent internal structure. Context was instrumental in locating the pragmatic 
meaning of texts; this knowledge guides a speaker or writer in the exploration of linguistic resources to convey meaning. Contextual nuances which undergird the use of language in human communication are not exhaustive. Fakuade (1998:17) posits that "language use (style) is governed by a wide range of contextual factors, including social and physical circumstances, identities, attitudes, abilities and beliefs of participants and relations holding or supposed to be holding between participants." The appropriate selection and use of language shows that it performs diverse social roles in discourse. This view corroborates Halliday (1970) who notes that "the particular form taken by the grammatical system of language is closely related to the social and personal needs that language is required to serve."

What stylistics does in textual analysis is to interpret textual meaning as represented by the formal properties of language. Across genres, style varies with individuals, topic, place, time and other constraints. Thus, the typical style in election campaign discourse may be extensively different from religious discourse. Speakers select language according to the context of speech and context of situation. The roles of language in any stylistic investigation of textual meaning is worthy of scholarly attention. The reason why language is so important to stylisticians is because the various forms, patterns and levels that constitute linguistic structure are an important index of the function of the text. The text's functional significance as discourse acts in turn as a gateway to its interpretation. While linguistic features do not of themselves constitute a text's 'meaning' account of linguistic features nonetheless serves to ground a stylistic interpretation and to help explain why, for the analysts, certain types of meaning are possible." Any rigorous stylistic research underscores creativity in language use as evident in written and spoken discourses. Leech and Short (1981) posit that style can be applied to both spoken and written, both literary and non-literary varieties of language, but by tradition, it is particularly associated with written literary texts." In a similar vein, Abraham (1981) opines that "the characteristic of a work may be analyzed in terms of: its diction, or choice of words; its sentence structure and syntax; the density and types of its figurative language; and its rhetorical aims and devices." To use language that is germane to contexts and situations, a speaker makes certain choices from his linguistic repertoire. Scholars have demonstrated that the objective of pragmatics is to show how users of any language can use the sentences obtainable in such a language to convey messages which are not directly or explicitly shown in the propositional content of the sentences.

Pragmatic and stylistic competences enable speakers to construct sentences that convey speaker-intended speech acts. Brumfit and Johnson (1979:118) opine that "the ability to compose sentences is not the ability we need to communicate. Communication only takes place when we make use of sentences to perform a variety of different acts of an essentially social nature. Thus we do not communicate by composing sentences, but by using sentences to make statements of different kinds, to desire, to record, to classify, and so on, or to ask questions, make requests, give orders, etc. Knowing what is involved in putting sentences together correctly is only one part of what we mean by knowing a language, and it has very little value on its own. It has to be supplemented by knowledge of what sentences contain as in their normal use as a means of communication."

The dynamics of texts across genres captures the communion between language and context; see Susan Hunston (2013) who examines the two-way direction of fit between context and language. Without the performance of illocutionary acts in discourse, the relationship between context and language (meaning) cannot be ascertained. Via pragmatic and stylistic competences speakers effectively convey textual messages. Considering its scope, knowledge of pragmatics facilitates the use of elements of communication to achieve illocutionary goals. Savas $\mathrm{L}$. Tsohatzidis (1994:2) contends that "the study of illocutionary acts should be acknowledged as an indispensible component of the study of meaning." Sentences mean by virtue of the speech acts they contain, as used intentionally by speakers or writers. Indeed, the pragmatic and stylistic constraints which underpin linguistic choices in texts, is often obvious to the analyst. Thus, Crystal and Varley (1993:42) submits that "pragmatics is the study of the factors that govern our choice of language (sounds, construction, words) in social interaction, 
and the effects of our choice upon others. The subject includes the cooperation in our speaking behaviour and it thus involved when we use language to convey politeness, intimacy, playfulness, rudeness, awkwardness and a range of other "social attribute ${ }^{1}$." The use of language in a definite sense to convey a wide range of social attributes essentially differentiates sentences from utterances. Dittmar (1976:163) rightly notes that "utterances are not only grammatical or acceptable, but must also be assessed by the extent to which they are successful and appropriate to the context, by the way in which they are effected as actions, and with what results. In other words, the analysis must include those aspects which, in a theory of communicative competence, should decide the way in which sentences in a particular phonological and syntactic structure are regarded as functional for a given situation. This is where the concept of speech acts comes into its own. Sentences that are identical in their formal grammatical structure can, according to the situational context, be commands, requests, demands or apologies. Conversely, two grammatically different sentences can be understood as one and the same speech act. Furthermore, speech acts have immediate pragmatic consequences: a person who makes a promise or apologies for something is performing an action which has consequences both for himself and for others." In a similar vein, Austin (1962:119) notes that "saying something will often, or even normally, produce certain consequential effects upon the feelings, thoughts, or actions of the audience, or of the speaker, or of other persons; and it may be done with the design, intention or purpose of producing them... ${ }^{2}$

\section{THEORETICAL UNDERPINNINGS}

The study hinges on Bach and Harnish (1979) and Lawal's Communicative Model Theory for the analysis of data.

\section{Bach and Harnish's Speech Act Theory}

The approach of Kent Bach and Robert M. Harnish to Speech Acts is intention and 'inference' based. They contend that for speakers to perform illocutionary acts, it is intended that listeners have the understanding of the acts. It is their claim that the act of conversation or interactional talk has to involve an inferential process. Their terminology Speech Act Schemata (SAS) refers to an inevitable part of the inferential process in a communicative event. To them, mutual contextual beliefs (MCBs) between a speaker and his hearer facilitate the inferential process, as the inference made or is expected to be made by the hearer does not depend on what the speaker says but on the contextual knowledge shared commonly by the speaker and hearer in discourse. To infer what S (speaker) is saying H (hearer) depends also on the Presumption of Literatures (PL). H should know when the linguistic communication of $S$ is 'within or without' the bounds of literalness, and if $S$ is speaking in a non-literal dimension, $\mathrm{H}$ should not only acknowledge it, but should also be able to understand what such speech by S means; the hearer should have a mastery of the acts in S's non-literal language. The non-literal language involves the use of indirect speech acts. Apart from MCBs, Bach and Harnish recognize other types of beliefs (shared by an entire linguistic community) which the hearer relies on for his inferences. These are:

(i) Linguistic Presumption (LP); and

(ii) Communicative Presumption (CP).

Linguistic Presumption (LP) refers to the moral belief that members of a Linguistic Community (LC) share on the particular language (L) in question. Therefore, any expression (e) uttered by a member to any member of the community, is taken by $\mathrm{S}$ for granted that is, $\mathrm{S}$ presupposes that $\mathrm{H}$ will be able to identify what is being said. Whenever a member says something in $\mathrm{L}$ to another member, the speaker is doing so with some known illocutionary intent. If $\mathrm{H}$ does not think the (CP) is operative then $\mathrm{H}$ has no grounds to infer any illocutionary intent from S's utterance. They contend that an act is communicatively successful as soon as the hearer recognizes the speaker's illocutionary intention. They therefore contend 'that the intended effect of an act of communication is not just any effect produced by means of recognition of the intention to produce certain effects on (or in) the hearer.' They restricted perlocutionary acts to effects produced intentionally, arguing that 
Student Union Election Discourse in Nigeria: The Stylo-pragmatics

only such effects constitute the reason for a given speech act.

They recognize several types of strategies in the inferential process:

a. Locutionary Strategy - the hearer's inference from the locutionary act or the utterance per se and what the utterance means in L. This is based on H's knowledge of the language, the LP, the CP and MCBs.

b. Direct Literal Strategy - H infers from the PL whether or not S means what he says and nothing else. This helps $\mathrm{H}$ to identify the act.

c. Literally Based Indirect Strategy - H depends on the MCBs, CP, and the utterance to determine whether, under the circumstance there is some action connected with the literal utterance.

d. Direct Non-literal Strategy - from the MCBs, CP, and the utterance, H's knowledge of the literal meaning of the utterance, $\mathrm{H}$ infers that S's utterance must be non-literal and indirect since another act is connected with the overt one which $\mathrm{H}$ recognizes.

e. Non-literally Based Indirect Strategy - the CP, the utterance, and MCBS lead H to infer that S's utterance must be non-literal and indirect since another illocutionary act is connected with it (pp. 70-80).

They use the SAS chart to explain the fact that $\mathrm{H}$ uses his knowledge of the language used by S along with MCBs, $\mathrm{CP}$ and PL to infer whether or not a particular utterance is literal or direct. If $\mathrm{H}$ concludes that $\mathrm{S}$ is speaking non-literally, he can seek an alternative explanation for the utterance.

Bach and Harnish's theory emphasize the need for the hearer to recognize a speaker's intention which they call 'Reflexive-intentions' (R-intentions). To communicate according to them, is to express an attitude such as belief, an intention, a desire, etc., and 'For $\mathrm{S}$ to express an attitude is for $\mathrm{S}$ to R-intend the hearer to think $\mathrm{S}$ has that attitude'.

Bach and Harnish recognize two broad categories of illocutionary acts: communicative and non-communicative. While the former requires the recognition of S's R-intention, the latter does not. They submit that there are four main categories of communicative illocutionary acts: Constatives, Directives, Commissives and Acknowledgements. These four main categories correspond roughly to Austin's Expositives, Exercitives, Commissives, and Behabitives respectively and closely to Searle's Representatives (Assertives), Directives, Commissives and Expressives, differing mainly in their characterizations. There are two classes of non-communicative illocutionary acts: Effectives and Verdictives, corresponding rougly to Searle's Declarations. A detailed account of the categories established by Bach and Harnish are speech acts which express the speaker's belief and intention, or, at least the implication or desire, that the hearer form (or continue to hold) a like belief. Fifteen subcategories of this group are recognized as follows: Assertives, Informatives, Confirmatives, Concessives, Retractives, Assentives, Dissentives, Disputatives, Responsives, Suggestives and Suppositives (ibid. pp. 42-46).

According Bach and Harnish (ibid.), Assertives are 'characterized by S's expression of belief that the hearer (H) also believes that P'. Examples of Assertives are affirm, allege, assert, aver, avow, declare and deny .

Informatives are speech acts in which $\mathrm{S}$ expresses the belief that $\mathrm{P}$ and also 'the intention that $\mathrm{H}$ form the belief that P.' Examples are advise, announce, appraise, disclose, inform, insist, notify, point out, report, reveal, tell, and testify.

In Descriptive speech acts, $\mathrm{S}$ declares that a particular quality is possessed by a person, place or thing. That is, $\mathrm{S}$ expresses 'the belief that $\mathrm{O}$ is $\mathrm{F}$ ' and 'the intention that $\mathrm{H}$ believes that $\mathrm{O}$ is $\mathrm{F}$ '. Examples are appraise, asses, call, categorize, characterize, classify, date, describe, diagnose and evaluate.

In Directives, the speaker's attitude toward a future action by the hearer $(\mathrm{H})$ and the speaker's intention or 
desire that $\mathrm{H}$ considers his utterance as reason to act $(\mathrm{A})$ is expressed. Six subcategories of illocutionary acts are listed under this category: Requestives, Questions, Requirements, Prohibitives, Permissives, Advisories.

Questions are 'special cases of requests in that what is requested is that the hearer provide the speaker with certain information'. A speech act is considered a question if $\mathrm{S}$ expresses 'the desire that $\mathrm{H}$ tell $\mathrm{S}$ whether or not $\mathrm{P}$ ' and 'intention that $\mathrm{H}$ tell S whether or not P because of S's desire'. Examples of verb denoting Questions are ask, interrogate, query, questions, quiz, etc.

Advisories, they explain, is a speech act in which the speaker expresses the belief 'that there is (sufficient) reason for $\mathrm{H}$ to $\mathrm{A}$,' and 'The intention that $\mathrm{H}$ takes S's belief as (sufficient) reason for him to A'. Examples are advise, caution, counsel, propose, recommend, suggest, urge, warn, etc.

The third major category of speech acts established by Bach and Harnish, Commissives, is a speech act involving the undertaking of an obligation or proposal to undertake an obligation. Two main types of this category are distinguished: Promises and Offers.

$S$ promises $\mathrm{H}$ to $\mathrm{A}$ if $\mathrm{S}$ expresses 'the belief that his utterance obligates him to A', 'the intention to $\mathrm{A}$ ', and 'the intention that $\mathrm{H}$ believes that $\mathrm{S}^{\prime}$ s utterance obligates $\mathrm{S}$ to $\mathrm{A}$ and that $\mathrm{S}$ intends to A'. Contracting, Guaranteeing, etc. are examples of this category. Promises include: swear, vow, surrender and guarantee.

A speech act is said to be an Offer if $S$ expresses 'the belief that $S$ 's utterance obligates him to A on condition that $\mathrm{H}$ indicates he wants $\mathrm{S}$ to $\mathrm{A}$ ' and 'the intention that $\mathrm{H}$ believes that $\mathrm{S}$ 's utterance obligates $\mathrm{S}$ to $\mathrm{A}$ and that $\mathrm{S}$ intends to $\mathrm{A}$ on condition that $\mathrm{H}$ indicates he wants $\mathrm{S}$ to $\mathrm{A}^{\prime}$. Examples of verbs denoting speech acts in this category are volunteer, offer, and propose.

Acknowledgements, the final category of Bach and Harnish's communicative illocutionary acts, are very common in our day to day interaction. They express perfunctorily if not genuinely, certain feelings toward the hearer". Examples of verbs denoting members of this category are greet, thank, condole, apologize, congratulate, etc.

\section{Lawal's Communicative Model Theory}

Lawal (2012) posits that the Communicative Model theory is eclectic in nature because it is the totality of the submissions of predating stylistic theories. The theory explains the interaction between message and medium through socio-linguistic and rhetorical devises. Elements in the theory include:

\section{SPEAKER OR WRITER;}

2. MESSAGE (i.e.) writer's or speaker's impression in the form of ideas, beliefs, knowledge, feelings and attitudes, etc. on the one hand, or listener's or reader's impression decoded in the form of ideas, beliefs, knowledge, feelings, etc.;

3. MEDIUM i.e. writer's or speaker's expression encoded in the form of: (i) A rhetorical mode (the primary stylistic device which incorporates linguistic norms and directs pragmatic interpretation of textual properties); (ii) Linguistic 'norms', constants, variants, and deviants.

\section{METHODOLOGY}

In this study, we present data and analyze them by relying on pragmatic and stylistic theories as well as insights from related disciplines; thus, the analysis will be integrative. It does not follow a typical, traditional analytical approach because the purpose of this study is simply to locate the place of a wide range of linguistic disciplines in political discourses such as election campaign speeches.

\section{Presentation and Analysis of Data}

The analysis of datum 1-5 is as follows: 
Student Union Election Discourse in Nigeria: The Stylo-pragmatics

\begin{tabular}{|c|c|}
\hline Datum & Analysis \\
\hline $\begin{array}{l}\text { 1. Great students of our } \\
\text { great University, I greet } \\
\text { you all. I welcome you all. } \\
\text { Listen you all. Listen my } \\
\text { comrades. Because our } \\
\text { Institution must keep its } \\
\text { flag flying, we all have left } \\
\text { our other commitments to } \\
\text { come here. The common } \\
\text { good that unites us is our } \\
\text { strength. The common } \\
\text { vision that directs our } \\
\text { steps is our hope. When } \\
\text { we put all our differences } \\
\text { aside to keep Institution's } \\
\text { flag }\end{array}$ & 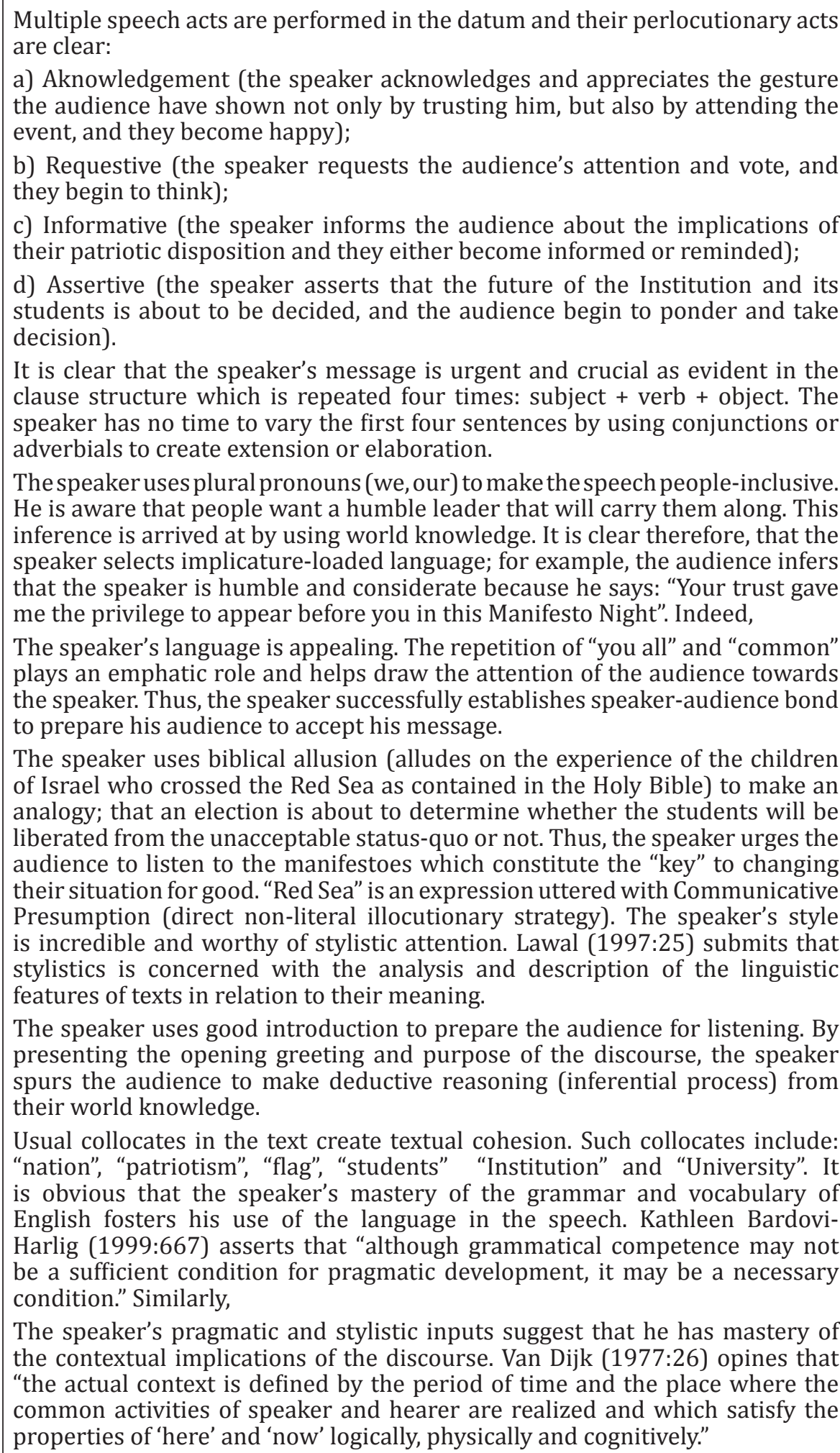 \\
\hline
\end{tabular}


2. You are the change you want to acquire. You are the revolution you desire. Aspire to get the job done. Acquire the revolution. It is a nonnegotiable desire. Freedom is man's non-negotiable desire. Progress is needed by humanity. Unity is strength. If our Student Union Government could not deliver the mandate for so long, then try the credible candidate. A vote for me is a vote for freedom, equity, transparency, accountability, pragmatism, revolution, progress and paradigm shift.

3. Students' rights remain violated. Is freedom of speech unimportant in true democracy? If this University must stop indiscriminate increase in school fees, you need a true leader, comrades. 0 mortals, you are born free yet you remain in perpetual bondage. Insensitive school authority results in oppression of students. Notorious school authority, then obnoxious regulations. Your toilets, classrooms, freedom of expression... Decide your future by this time tomorrow. Articulate, vibrant, astute and incredible comrades, decide your future by this time tomorrow.
The speech acts performed and their respective perlocutionary acts include:

a) Assertive (the speaker asserts that the audience have the human qualities it takes to transform their situation in University, and they feel acknowledged and convinced);

b) Requestive (the speaker requests the audience to take an action (participate in voting) that will change their plight, and they begin to decide/think);

c) Assertive (the speaker asserts that he has good qualities for good leadership, and they are persuaded). The speaker explores figurative language (metaphor) to make is message pungent. The use of metaphor makes the speech a successful direct call to action.

The repeated clause structure: SVC + SVC (Subject Verb Complement as in the first and second sentences); VO + VO (Verb Object as in the third and fourth sentences) as well as the alternate repetition of "aspire", "desire" and "acquire" make the speech appealing. There is a special use of the conditional clause in the text - it begins the sentence and recalls the past failures of SUG governments rather than ending the sentence and predicating a future state-of-affairs. With this structure, the sentence is able to perform multiple illocutionary acts: condemning, persuading, ascribing/describing and requesting. The arrangement of the text in terms of syntax and diction is creative. Like a typical, classical Greek orator or philosopher, the speaker presents a thoughtprovoking speech, which corroborates Aristotle's three steps of rhetoric: invention, arrangement and style. Apart from having some collocation range, the vocabulary (domain-suggestive abstract nouns: freedom, equity, progress, etc.) depict the universality of the message. The speaker is aware (world knowledge) that in political discourses such as election campaigns, the audience await impressive oration. Apart from making the hearers understand the speaker's Communicative Intention (as in Bach and Harnish's theorising), the speaker's language prowess also helps them decide on the speaker's credibility; because language is impressionistic, speakers are rated high when they show good command of English. Fakuade Gbenga (1998:15-16) notes that "good style ... consists in choosing the appropriate symbolization of the experience you wish to convey, from among a number of words whose meaning area is roughly, but only roughly, the same (by saying 'cat', for example, rather than 'pussy')."

The datum reveals the following speech acts and perlocutionary acts:

a) Assertive (the speaker asserts that the status-quo in the university is bad, and the audience become unhappy);

b) Requestive (the speaker requests the audience to vote for the right candidate, and they begin to decide). The text shows adjectives that are skilfully used3. The adjectives elaborate the message. This is important because the speaker is faced with the task of helping the hearers capture vividly, the status-quo being addressed. Allan (1986) submits that speech acts are directed at states-ofaffairs (worlds-spoken-of). Thus, the speaker hinges on appropriate adjectives as such to give his message contextual structure rather than making it exist in a vacuum. Sentence elements are omitted but with the use of skilful punctuation, the audience can infer the implied elements. The speaker is aware that his audience understand the points he makes (Communicative Presumption) even though he omits some sentence elements. Reminiscence is therefore a stylistic feature in the text. It is used to bluntly attack the status-quo. The text shows sentence variation that enables the speaker say much within a short time. David Harrah, cited in Savas (1994:375) notes that "most speech acts seem to be focused and directed. They are intended as coming from the agent and going to the receivers or audience. They are intended to have a certain point, and they are intended to be construed as having a certain point." At word and syntactic level, the speaker uses language effectively to convey intended message. 
Student Union Election Discourse in Nigeria: The Stylo-pragmatics

\begin{tabular}{|c|c|}
\hline & $\begin{array}{l}\text { William P. Alston, cited in Savas L. T. (1994:31) submit that "word meaning is } \\
\text { prior to sentence meaning in the order of the explanation of particular facts } \\
\text { (we explain the fact that a particular what it does by appealing to the meanings } \\
\text { of its constituents plus its structure). While sentence meaning is prior to word } \\
\text { meaning in the order of conceptual analysis, or explication. We explain the } \\
\text { concept of word meaning in terms of the contribution a word makes to the } \\
\text { meaning of sentences." }\end{array}$ \\
\hline $\begin{array}{l}\text { 4. They do not fight for } \\
\text { our interests. They do not } \\
\text { understand democracy. They } \\
\text { are not student leaders. They } \\
\text { are not student activists. } \\
\text { They lack the traits of } \\
\text { leadership. Yes, most past } \\
\text { Student Union Presidents. } \\
\text { Go out to vote tomorrow. } \\
\text { You have to be there. } \\
\text { Exercise your franchise. } \\
\text { No action, no revolution. }\end{array}$ & 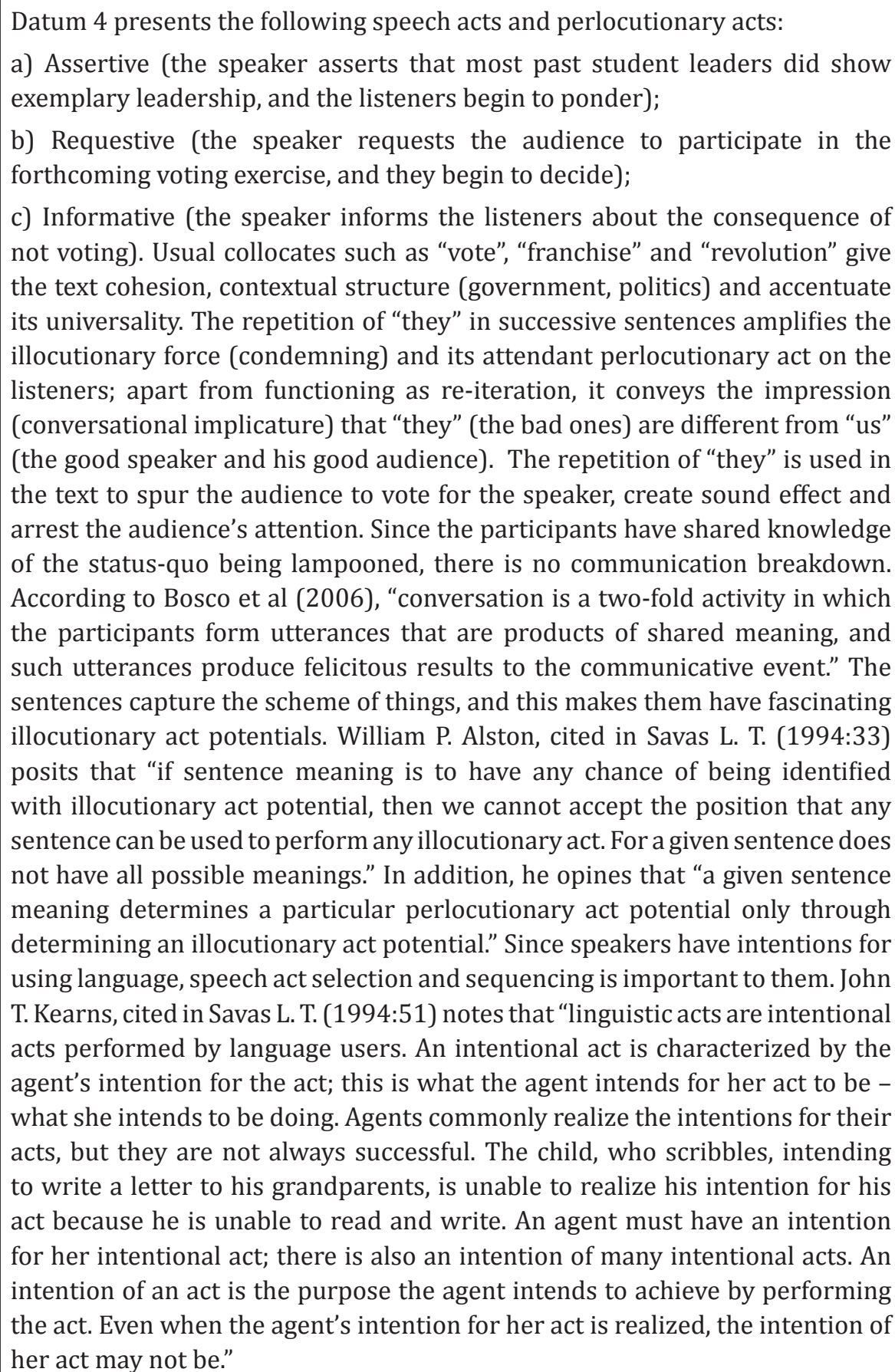 \\
\hline
\end{tabular}




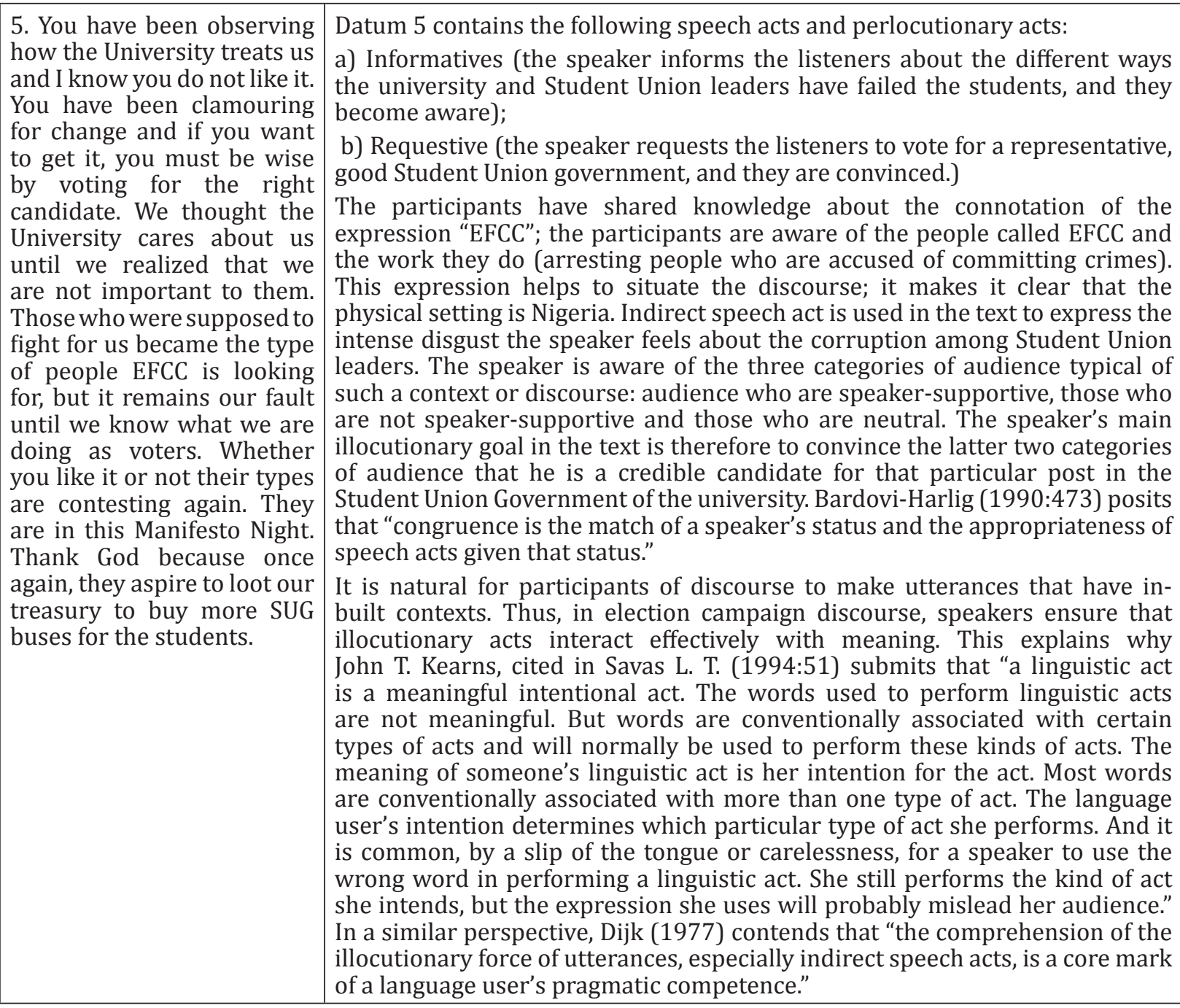

\section{DiscuSSION AND CONCLUSION}

To be able to use language efficiently, its signification potential must be shown in its use in spoken and written communication. Bennett (1998) posits that "language does serve as a tool for communication, but in addition, it is a 'system of representation' for perception and thinking." The transaction of meaning is crucial in political discourse as in all discourse genres. This is because discourse is essentially communication. According to David A. Brenders (1987:329) "one of the central issues involved in any systematic analysis of communication is the role of 'meaning' in conversation. One general trend in such analyses has been to regard meaning as the products of social action. While this approach promotes the sensible idea that communication is the product of social actors in context rather than the mere adherence to language rules, this position has tended to blur the distinction between semantic and pragmatic meaning, and illocutionary versus perlocutionary acts. As a result, slogans such as "Words don't mean, people mean," are used widely, while research proceeds with little or no discussion of whether this approach yields consistent and sensible analyses of meaning in communication." The use of pragmatic and stylistic features in human communication depicts language use as a rule-governed process. David A. Brenders (1987:331) argues that "speech act theory, as a part of the philosophy of language, has been concerned with analyzing the performance of linguistic acts (asserting, promising, questioning) as 
a rule-governed form of behaviour..." This partly why intended perlocutionary acts are achieved by speakers. Brenders (1987:344) further notes that "coherent conversation involves both the coordinated production of illocutionary acts and the management of the potential perlocutionary effects of utterances." The persuasive use of language in political speeches such as Student Union election speech is informed by topic, audience and occasion. These variables determine the speaker's choice of language. Apart from being fascinating, Student Union election discourses in Nigerian tertiary institutions are very persuasive and enchanting. The speaker's language strikes a balance between formality and informality. The use of informal expressions signals comradeship while formal expressions depict the speaker's credibility in terms of intellectual prowess and administrative ability; formality in choice of language makes the audience think a political aspirant is not a tout. During the discourse, the audience takes note of the speaker's command of the grammar and vocabulary of English. This background knowledge explains why speakers "clean up" their language before the Manifesto Night and rely heavily on high-sounding (magniloquent) dictions with which they either lampoon the status-quo or present their manifestoes. Having been given the nick-name, Plato, it can be inferred that the audience is aware that the speaker is an orator. The speaker does not merely use language to convey 'social system', but also to influence it.

To communicate persuasively in student union campaigns, speakers construct specific illocutionary-goalsdriven syntactic structures, use conjunctions to extend the discourse and establish cause-effect phenomena, repeat linguistic elements to arrest audience attention and emphasize messages, use figurative language to concretize message, allude to explain phenomena and make striking analogy.

\section{NOTES}

1. This view corroborates Kempson (1986) who opines that pragmatics is "the study of the general cognitive principles involved in the retrieval of information from an utterance."

2. Examining the textual functions of language, Halliday $(1971: 332,334)$ establishes three functions of language, two of such functions are as follows:

"1. The ideational function conveys the contents of a text; "it is through this function that the speaker or writer embodies in language his experience of the phenomena of the real world.

2. The interpersonal function comprises two levels of expressing the individual: the interactional and the personal level. It is concerned with the personal contribution of the speaker to the act of communication and with the speaker's attitude and options and her/his relation to the context."

3. The literature presents Ascriptive as a speech act category that uses adjectives to describe (or ascribe qualities to) objects/phenomena.

\section{REFERENCES}

Allan, Keith. (1986). Linguistic Meaning Vols. I and II. London: Routledge and Kegan Paul.

Austin, John. (1962). How to Do Things with Words. (Cambridge: Harvard University Press).

Bach, Kent \& Robert, Harmish (1979). Linguistic Communication and Speech Acts.

Cambridge, Massachusetts, The MIT Press, pp. 15, 17, 70-80.

Bardovi-Harlig, Kathleen and Beverly S. Hartford (1990). “Congruence in Native and Normative Conversations: Status Balance in the Academic Advising Session". In Language Learning, 40: 469-501. Retrieved from http://dx.doi.org/10.1111/ j.1467-1770.1990.tb00603.x. Cambridge: Polity Press, 250-279.

Brumfit, C. J. and Johnson, K. (1979). The Communicative Approach to Language Teaching.

Oxford: Oxford University Press.

American Research Journal of English and Literature

Page 10 
Student Union Election Discourse in Nigeria: The Stylo-pragmatics

Dittmar, Norbert. (1976). Sociolinguistics: A Critical Survey of Theory and Application. Edward Arnold.

Fakuade, Gbenga ed. (1998). Studies in Stylistics and Discourse Analysis. Yola: Paraclete Publishers.

Halliday, M. A. K. (1970). "Language Structure and Language Function”. In New Horizons in Linguistics. Ed. J. Lyons, Harmondsworth: Penguin. (pp. 140 - 165).

Halliday, M. A. K. (1971). Cohesion in English. London: Longman.

John, T. Kearns (1994). "Meaning, Structure and Speech Acts". In Savas L. T. (ed.) Foundations of Speech Act Theory. London: Routledge.

Lawal, Adebayo (2012). "Aspects of a Stylistic Theory and the Implications for Practical Criticism." In Adebayo Lawal (ed.), Stylistics in Theory and Practice. Ilorin: Applied Linguistics Study Group (ALSG), University of Ilorin, p. 38.

Leech, Geoffrey \& Short, M. H. (1981). Style in Fiction: An Introduction to English Fictional Prose. London: Longman Group Limited.

Savas, L. Tsohatzidis Ed. (1994). Foundations of Speech Act Theory. London: Routledge. Susan Hunston (2013). "Systemic Functional Linguistics, Corpus Linguistics, and the Ideology of Science". Text \& Talk 33(4-5):617-640.

Van Dijk Teun A. (1977). Text and Context. London: Longman Group Ltd.

Citation: Acheoah, John Emike, Olaleye, Joel Iyiola, Hamzah Abdulraheem, "Student Union Election Discourse in Nigeria: The Stylo-pragmatics". American Research Journal of English and Literature; V3, I1; pp:1-11.

Copyright (C) 2017 Acheoah, John Emike, Olaleye, Joel Iyiola, Hamzah Abdulraheem, This is an open access article distributed under the Creative Commons Attribution License, which permits unrestricted use, distribution, and reproduction in any medium, provided the original work is properly cited. 